\title{
Plate fixation of extra-articular fractures of the proximal phalanx: do new implants cause less problems?
}

\author{
Pascale Brei-Thoma • Esther Vögelin • \\ Torsten Franz
}

Received: 5 September 2014/Published online: 11 January 2015

(C) Springer-Verlag Berlin Heidelberg 2015

\begin{abstract}
Background Limited range of finger motion is a frequent complication after plate fixation of phalangeal fractures. The purpose of this study was to evaluate the results of plate fixation of extra-articular fractures of the proximal phalanx using current low-profile mini-fragment-systems. Methods From 2006 to 2012, 32 patients with 36 extraarticular fractures of the proximal phalanx of the triphalangeal fingers were treated with open reduction and plate fixation (ORPF) using 1.2 and $1.5 \mathrm{~mm}$ mini-fragment systems. Patients presenting with open fractures grade 2 and 3 or relevant laceration of adjacent structures were excluded from the study. We retrospectively evaluated the rate of mal-union or non-union after ORPF, the need for revision surgery, for plate removal, and for tenolysis. Data were analyzed for further complications with regard to infections or complex regional pain syndrome (CRPS).

Results No infections were noted. Five patients developed transient symptoms of CRPS. Six weeks postoperatively, total active finger motion (TAM) averaged $183^{\circ}$, and all 32 patients underwent formal hand therapy. At the latest follow-up or at the time of plate removal, respectively, the mean TAM improved to $213^{\circ}$. Extension lag of proximal interphalangeal joints was found in $67 \%$ of all fractured fingers. Secondary surgery was necessary in 14 of 32 patients ( 2 corrective osteotomies, 12 plate removals
\end{abstract}

P. Brei-Thoma · E. Vögelin · T. Franz

Department of Plastic and Hand Surgery, Inselspital Bern,

Bern, Switzerland

T. Franz $(\bowtie)$

Hand Surgery Service, Department of Surgery,

Uster Hospital, Uster, Switzerland

e-mail: torsten.franz@spitaluster.ch including 7 procedures explicitly because of reduced mobility).

Conclusions Despite of new implant designs significant problems persist. Adhesions of extensor tendons leading to limited range of finger motion are still the most frequent complications after ORPF of proximal phalangeal fractures, even in absence of significant soft-tissue damage. Level of evidence Therapeutic, Retrospective, Level IV.

Keywords Fracture $\cdot$ Finger $\cdot$ Proximal phalanx - Internal fixation - Complications

\section{Introduction}

Phalangeal fractures constitute about $23 \%$ of all fractures occurring from the hand through the forearm, and most phalangeal fractures occur in the proximal phalanx $[1,2]$. Various concepts exist for conservative and surgical treatment of extra-articular fractures of the proximal phalanges. Their shared aim is to achieve solid bone union and maximize motion, hence restoring the hand function to maximum potential. Unstable phalangeal fractures regularly require surgical treatment. A wide range of appropriate implants are currently available for internal fixation. However, several authors have shown that a stable construct is only but one of many outcome factors in surgical treatment of phalangeal fractures. Fracture pattern, degree of soft tissue damage, invasiveness of surgical approach, and the postoperative rehabilitation protocol are important factors to be considered. A significant disadvantage of plate fixation is that the implant may interfere with the excursion of the extensor hood. Limited range of finger motion is a frequent complication after plate fixation of phalangeal fractures and may lead to unsatisfactory results [3, 4]. More 
recently, dedicated implants for internal fixation of phalangeal fractures have come onto the market to address some of these concerns. Those titanium plates are much easier to contour to bone, feature lower profiles, improved design, and enable fracture fixation using locking screws.

The purpose of this study was to examine the effect of using these improved plates on complications and total active range of motion (TAM) following fixation of extraarticular fractures of the proximal phalanges in absence of significant trauma to the soft tissues. Does internal fixation using these new implants result in less tendon adhesion, and thus enable improved postoperative range of motion?

\section{Patients and methods}

Using keyword-based search function of the computerized clinical information system, we retrospectively reviewed the operative and clinical records of 74 consecutive patients having 81 extra-articular basal or diaphyseal fractures of the proximal phalanx, treated with open reduction and plate fixation using current 1.2 or $1.5 \mathrm{~mm}$ mini-fragment systems in the years between 2006 and 2012. All patients were either operated on our institution $(n=71)$ or were referred to our department for immediate postoperative aftercare $(n=3)$. According to predefined exclusion criteria (intra-articular fractures, fractures of the thumb, grade II and III open fractures or concomitant laceration of adjacent structures), 38 patients were excluded from further evaluation. Four patients were lost to follow-up, since their place of residence was not in the vicinity and aftercare took place elsewhere.

A total of 32 patients (15 females, 17 males) having 36 extra-articular fractures were included in this retrospective study for further evaluation of clinical and radiological results. The study has been approved by institutional review board.

The indications for open reduction and plate fixation were unstable or potentially unstable fractures in all patients. Twenty-six fractures were stabilized using plates of the 1.2/1.5 mm Aptus ${ }^{\circledR}$ Hand System (Medartis Ltd., Basle, Switzerland). Furthermore, in 7 fractures the 1.2/ $1.5 \mathrm{~mm}$ TriLock equipment of the Aptus ${ }^{\circledR}$ Hand System, providing locking screws, was applied. Three fractures were fixed using the 1.5-mm Compact Hand System
(Synthes Ltd., Zuchwil, Switzerland). In 12 factures, bony defects were filled with allogenic cancellous bone (Tutoplast $^{\circledR}$, Tutogen Medical, Neunkirchen, Germany). For open reduction and plate fixation, a standard dorsal approach with longitudinal splitting of the central slip was used in all cases.

All patients followed a standardized postoperative rehabilitation protocol. A removable splint was applied for 4 weeks after surgery, and early active motion of the digits was initiated under supervision of a hand therapist within 2-4 days. All patients were evaluated by a hand surgeon after 2, 4, 6, 12, 18 weeks and longer, according to the individual setting. Standard radiographs of the fingers (ap view and lateral view) were obtained to assess fracture healing 2 weeks and 6 weeks after osteosynthesis. Mean follow-up was 10 months, ranging from 5 to 42 months. Active range of motion (ROM) of each joint of the affected fingers and total active motion in all three finger joints (TAM, sum of flexion minus sum of extension lag) were regularly measured at follow-up. Evaluating the complications after plate fixation, postoperative TAM after 6 weeks, TAM at the latest follow-up, or TAM before and after hardware removal and tenolysis was assessed and classified using the Belsky Score (Table 1) [5].

\section{Results}

Fracture location and types of fracture

Fractures were equally distributed between left and right hands ( $n=18$ on each side). The small finger was fractured most often $(n=15)$, followed by fractures of ring finger $(n=10)$, middle finger $(n=6)$, and index finger $(n=5)$. Types of fracture are summarized in Table 2. Six patients presented with open fractures grade I (minor skin lesion). Six patients suffered from additional injury at the affected hand: in one case, fracture of the proximal phalanx was combined with a closed diaphyseal fracture of the same-ray metacarpal bone treated with additional plate fixation. In two cases, additional fractures at adjacent rays were addressed with additional plate fixation (one subcapital metacarpal fracture, one intra-articular fracture of an adjacent proximal phalanx). One patient experienced fracture of the proximal phalanx combined with same-

Table 1 Belsky score

\begin{tabular}{ll}
\hline Belsky score & \\
\hline Excellent & TAM greater $250^{\circ}$, no symptoms, no deformity \\
Good & TAM between $210^{\circ}$ and $250^{\circ}$ \\
Moderate & TAM between $180^{\circ}$ and $210^{\circ}$, minimal angular or rotational deformity \\
Poor & TAM less than $180^{\circ}$ \\
\hline
\end{tabular}


Table 2 Fracture characteristics

\begin{tabular}{lc}
\hline Fracture type & Total \\
\hline Basal transverse & 18 \\
Transverse & 10 \\
Oblique & 6 \\
Spiral & 2 \\
\hline
\end{tabular}

sided distal radius fracture, also treated with additional plate fixation. In two patients, additional injuries were treated conservatively (one avulsion fracture of a collateral ligament, one non-displaced extraarticular fracture of adjacent proximal phalanx). The postoperative rehabilitation protocol did not differ in these patients. Regarding postoperative range of motion, the additional injuries did not lead to a worse outcome in this group.

\section{Complications}

No infection and no wound-related complications were observed. In 5 patients, transient symptoms of complex regional pain syndrome (CRPS) like pain combined with trophic changes, vasomotor or sudomotor dysfunction were noted. Whether these patients fulfilled the Budapest criteria for CRPS [6] could not be defined retrospectively. Among them, one patient experienced fracture of the proximal phalanx in combination with a distal radius fracture. The other four patients did not have additional injury to the affected hand.

\section{Malunion/delayed union}

There was one patient with a delayed union accompanied by implant failure (Fig. 1). That fracture healed without

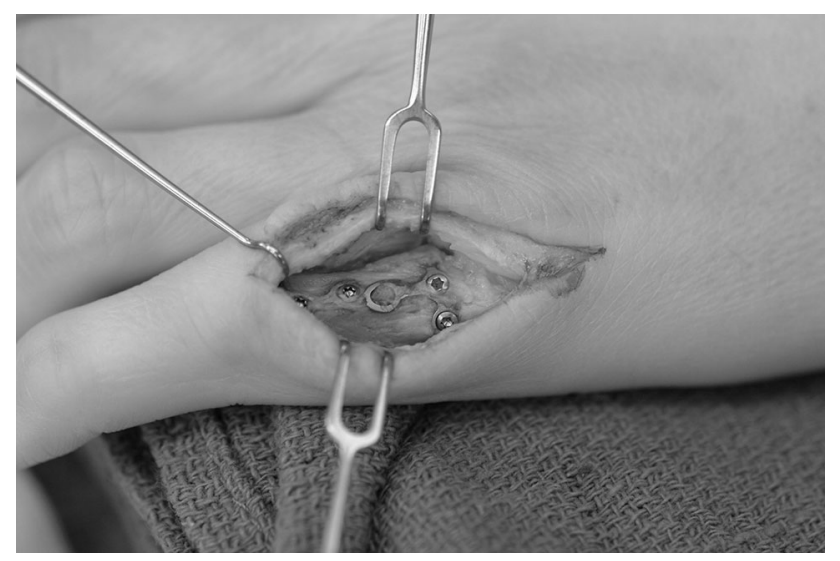

Fig. 1 Intraoperative situs at revision surgery showing a delayed union after plate osteosynthesis of an oblique fracture of the proximal phalanx of the little finger, accompanied by implant failure. After plate removal and tenolysis, the fracture healed without surgical reintervention surgical re-intervention. Three patients experienced rotational malunion, leading to revision surgery in two of them. In both patients, a corrective osteotomy of the proximal phalanx was performed. Regarding postoperative motion, those patients achieved a comparable outcome after revision surgery; thus they were included in further evaluation. Their mean follow-up was prolonged to 18 months.

\section{Postoperative range of motion}

Hand therapy was instituted in all patients. Six weeks postoperatively, an average TAM of $183^{\circ}$ was found, ranging from $50^{\circ}$ to $310^{\circ}$ ( $n=29$ fractures). PIP joint extension lag was $18^{\circ}$ on average, ranging from $0^{\circ}$ to $60^{\circ}$ (Fig. 2). According to the Belsky classification, 8 fingers were rated to have excellent motion, 1 finger had good motion, and 2 fingers had moderate motion. In 18 fractures, however, TAM at 6 weeks postoperatively was rated as poor. At final follow-up, or at the time of plate removal and tenolysis, respectively, an improved average TAM of $213^{\circ}$ was found (range $100^{\circ}-285^{\circ}, n=29$ fractures). Nine fingers were rated to have excellent motion, 9 fingers good motion, and 3 fingers moderate motion. In 8 fingers, however, TAM was still rated as poor. Extension lags of the PIP joints were found in $67 \%$ of all fractured fingers (Tables 3, 4).

\section{Plate removal}

In 12 patients, plate removal was necessary 4 to 35 months after internal fixation. In seven patients, plate removal and tenolysis were explicitly performed to improve restricted motion. In these seven patients, an average TAM of $198^{\circ}$ was noted preoperatively. Following plate removal,

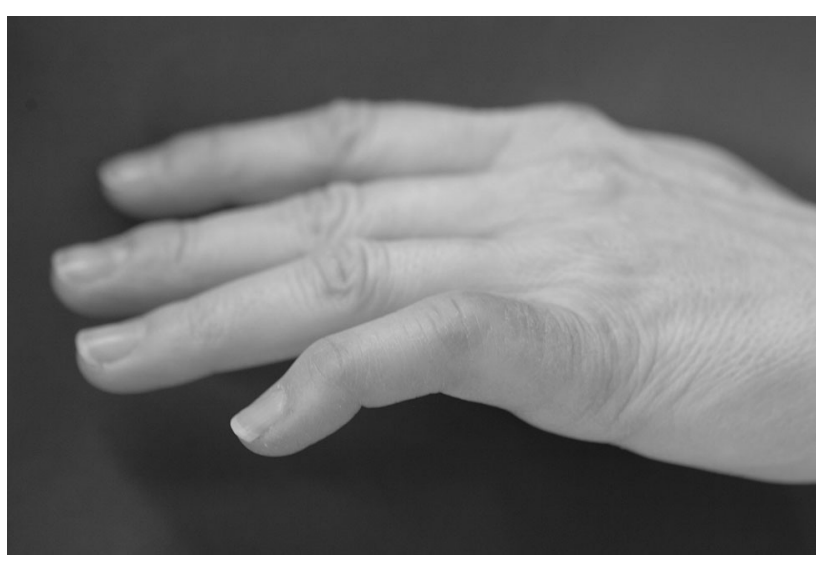

Fig. 2 Functional result 8 months after open reduction and plate fixation of a proximal phalanx fracture of the little finger. Note the significant extension lag of the proximal interphalangeal joint 
Table 3 Individual patient data

\begin{tabular}{|c|c|c|c|c|c|c|c|c|c|c|}
\hline Pat & Sex & Age & Finger & $\begin{array}{l}\text { Type of } \\
\text { fracture }\end{array}$ & $\begin{array}{l}\text { Finger TAM } \\
6 \text { weeks } \\
\text { postop }\left(^{\circ}\right)\end{array}$ & $\begin{array}{l}\text { PIP extension } \\
\text { lag } 6 \text { weeks } \\
\text { postop }\left(^{\circ}\right)\end{array}$ & $\begin{array}{l}\text { Finger TAM } \\
\text { at final } \\
\text { follow-up }\left(^{\circ}\right)\end{array}$ & $\begin{array}{l}\text { PIP extension } \\
\text { lag at final } \\
\text { follow-up }\left(^{\circ}\right)\end{array}$ & $\begin{array}{l}\text { Plate } \\
\text { removal }\end{array}$ & Remarks \\
\hline 1 & M & 21 & Middle & $\begin{array}{c}\text { Diaphyseal } \\
\text { transverse }\end{array}$ & 240 & 10 & 250 & 0 & Yes & \\
\hline 2 & M & 54 & Little & $\begin{array}{l}\text { Basal } \\
\text { transverse }\end{array}$ & 165 & 30 & 115 & 15 & No & \\
\hline 3 & F & 47 & Little & Spiral & 260 & 20 & 230 & 30 & Yes & \\
\hline 4 & F & 34 & Ring & Oblique & 160 & 20 & 165 & 20 & No & $\begin{array}{l}\text { Rotational } \\
\text { malposition } \\
\text { (corrective } \\
\text { osteotomy) }\end{array}$ \\
\hline 5 & M & 31 & Little & $\begin{array}{c}\text { Diaphyseal } \\
\text { transverse }\end{array}$ & 310 & 0 & 280 & 0 & Yes & \\
\hline 6 & $\mathrm{~F}$ & 23 & Ring & $\begin{array}{l}\text { Basal } \\
\text { transverse }\end{array}$ & & & 160 & 30 & Yes & \\
\hline 7 & F & 43 & Little & Oblique & 140 & 30 & 255 & 20 & Yes & $\begin{array}{l}\text { Delayed union, } \\
\text { dystrophic } \\
\text { changes }\end{array}$ \\
\hline \multirow[t]{2}{*}{8} & M & 40 & (a) Ring & $\begin{array}{l}\text { Basal } \\
\text { transverse }\end{array}$ & 160 & 35 & 210 & 15 & No & $\begin{array}{l}\text { Rotational } \\
\text { malposition }\end{array}$ \\
\hline & & & (b) Little & $\begin{array}{l}\text { Basal } \\
\text { transverse }\end{array}$ & 140 & 35 & 160 & 25 & & \\
\hline 9 & M & 24 & Middle & $\begin{array}{l}\text { Basal } \\
\text { transverse }\end{array}$ & 125 & 20 & 185 & 15 & No & \\
\hline 10 & M & 63 & Index & $\begin{array}{c}\text { Diaphyseal } \\
\text { transverse }\end{array}$ & 150 & 20 & 225 & 20 & Yes & \\
\hline 11 & F & 39 & Little & $\begin{array}{l}\text { Basal } \\
\text { transverse }\end{array}$ & & 20 & & 10 & No & \\
\hline 12 & M & 44 & Little & $\begin{array}{l}\text { Basal } \\
\text { transverse }\end{array}$ & 190 & 20 & 205 & 0 & No & \\
\hline 13 & M & 54 & Middle & $\begin{array}{l}\text { Basal } \\
\text { transverse }\end{array}$ & & 5 & & & No & \\
\hline \multirow[t]{2}{*}{14} & F & 63 & (a) Ring & $\begin{array}{l}\text { Basal } \\
\text { transverse }\end{array}$ & 150 & 20 & 225 & 20 & Yes & $\begin{array}{l}\text { Dystrophic } \\
\text { changes }\end{array}$ \\
\hline & & & (b) Little & $\begin{array}{l}\text { Basal } \\
\text { transverse }\end{array}$ & 150 & 10 & 190 & 25 & & \\
\hline \multirow[t]{2}{*}{15} & $\mathrm{~F}$ & 23 & (a) Ring & $\begin{array}{c}\text { Diaphyseal } \\
\text { transverse }\end{array}$ & 280 & 0 & 280 & 0 & Yes & \\
\hline & & & (b) Little & $\begin{array}{l}\text { Basal } \\
\text { transverse }\end{array}$ & 295 & 10 & 285 & 20 & & \\
\hline 16 & M & 56 & Index & Oblique & 170 & 15 & 235 & 10 & Yes & \\
\hline \multirow[t]{2}{*}{17} & F & 53 & (a) Middle & $\begin{array}{l}\text { Basal } \\
\text { transverse }\end{array}$ & 150 & 25 & 230 & 20 & No & \\
\hline & & & (b) Little & $\begin{array}{l}\text { Basal } \\
\text { transverse }\end{array}$ & 130 & 25 & 235 & 15 & & \\
\hline 18 & M & 43 & Ring & $\begin{array}{l}\text { Basal } \\
\text { transverse }\end{array}$ & & 10 & & 10 & No & $\begin{array}{l}\text { Dystrophic } \\
\text { changes }\end{array}$ \\
\hline 19 & F & 63 & Little & $\begin{array}{l}\text { Basal } \\
\text { transverse }\end{array}$ & 105 & 20 & 170 & 50 & Yes & $\begin{array}{l}\text { Dystrophic } \\
\text { changes }\end{array}$ \\
\hline 20 & $\mathrm{~F}$ & 44 & Middle & $\begin{array}{c}\text { Diaphyseal } \\
\text { transverse }\end{array}$ & 235 & 20 & 270 & 15 & No & \\
\hline 21 & F & 64 & Ring & Oblique & 145 & 15 & 220 & 20 & Yes & $\begin{array}{l}\text { Dystrophic } \\
\text { changes }\end{array}$ \\
\hline 22 & M & 32 & Index & $\begin{array}{c}\text { Diaphyseal } \\
\text { transverse }\end{array}$ & & 5 & & & No & \\
\hline
\end{tabular}


Table 3 continued

\begin{tabular}{|c|c|c|c|c|c|c|c|c|c|c|}
\hline Pat & Sex & Age & Finger & $\begin{array}{l}\text { Type of } \\
\text { fracture }\end{array}$ & $\begin{array}{l}\text { Finger TAM } \\
6 \text { weeks } \\
\text { postop }\left(^{\circ}\right)\end{array}$ & $\begin{array}{l}\text { PIP extension } \\
\text { lag } 6 \text { weeks } \\
\text { postop }\left(^{\circ}\right)\end{array}$ & $\begin{array}{l}\text { Finger TAM } \\
\text { at final } \\
\text { follow-up }\left(^{\circ}\right)\end{array}$ & $\begin{array}{l}\text { PIP extension } \\
\text { lag at final } \\
\text { follow-up }\left(^{\circ}\right)\end{array}$ & $\begin{array}{l}\text { Plate } \\
\text { removal }\end{array}$ & Remarks \\
\hline 23 & F & 35 & Little & $\begin{array}{l}\text { Diaphyseal } \\
\text { transverse }\end{array}$ & 110 & 20 & & & No & \\
\hline 24 & $\mathrm{~F}$ & 55 & Little & $\begin{array}{l}\text { Basal } \\
\text { transverse }\end{array}$ & & & 135 & 60 & Yes & \\
\hline 25 & $\mathrm{~F}$ & 91 & Ring & Spiral & 260 & 20 & & & No & \\
\hline 26 & $\mathrm{~F}$ & 39 & Little & $\begin{array}{l}\text { Basal } \\
\text { transverse }\end{array}$ & 190 & 0 & 240 & 0 & No & \\
\hline 27 & M & 44 & Ring & $\begin{array}{l}\text { Diaphyseal } \\
\text { transverse }\end{array}$ & 255 & 0 & 260 & 0 & No & \\
\hline 28 & M & 21 & Index & Oblique & 175 & 0 & 175 & 0 & No & \\
\hline 29 & $\mathrm{~F}$ & 73 & Little & $\begin{array}{l}\text { Diaphyseal } \\
\text { transverse }\end{array}$ & 50 & 30 & 100 & 40 & No & \\
\hline 30 & M & 44 & Index & Oblique & 155 & 15 & & & No & \\
\hline 31 & M & 43 & Middle & $\begin{array}{l}\text { Diaphyseal } \\
\text { transverse }\end{array}$ & 255 & 15 & 255 & 15 & No & \\
\hline 32 & M & 41 & Ring & $\begin{array}{l}\text { Basal } \\
\text { transverse }\end{array}$ & & & 230 & 10 & No & $\begin{array}{l}\text { Rotational } \\
\text { malposition } \\
\text { (corrective } \\
\text { osteotomy) }\end{array}$ \\
\hline
\end{tabular}

Table 4 Functional results in $N=29$ patients with complete data sets

\begin{tabular}{lll}
\hline & $\begin{array}{l}6 \text { weeks } \\
\text { postop }\end{array}$ & $\begin{array}{l}\text { Final follow-up } \\
>12 \text { weeks or at } \\
\text { time of second surgery }\end{array}$ \\
\hline Fractures $(N)$ & 29 & 29 \\
Mean TAM $\left(^{\circ}\right)$ & 183 & 213 \\
Range of TAM $\left(^{\circ}\right)$ & $50-310$ & $100-285$ \\
Mean PIP joint extension lag $\left(^{\circ}\right)$ & 18 & 18 \\
Range of PIP extension lag $\left(^{\circ}\right)$ & $0-60$ & $0-60$ \\
Belsky score & & \\
Excellent $(N)$ & 8 & 9 \\
Good $(N)$ & 1 & 9 \\
Moderate $(N)$ & 2 & 3 \\
Poor $(N)$ & 18 & 8 \\
\hline
\end{tabular}

extensor tenolysis and subsequent hand therapy, the average TAM improved to $242^{\circ}$.

\section{Discussion}

Fractures of the proximal phalanx are common injuries, and well-reduced fractures can be treated using functional conservative casts [7-9]. However, the ideal treatment of unstable fractures remains controversial. Management of these cases depends on several factors, including fracture location, fracture type, patient factors, and surgeon preference.
Plate fixation of phalangeal fractures is intended to provide rigid internal fixation to facilitate early movement and thereby minimize joint and tendon complications. However, complications of plate fixation are not rare and they may lead to significant loss of hand function $[3,4,10]$. Apart of malunion or nonunion, the chief concerns associated with ORPF are tendon adhesions and loss of motion in the PIP joint. In recent years, technical advancements have been achieved with the use of mini-fragment plates for stabilization of phalangeal fractures. In spite of these new implants that should reduce adhesion to the extensor tendons, studies suggest that postoperative finger motion after ORPF is still poor. Our current findings are consistent with previously reported results $[3,4,11,12]$. Stern et al. quoted complication rates up to $67 \%$ following stainless steel plate fixation of phalangeal fractures. TAM greater than $210^{\circ}$ was achieved in only 5 of 9 cases [12]. Page and Stern reported high complication rates and limited range of motion after plate fixation of metacarpal and phalangeal fractures [4]. Assessing results of plate fixation in fractures of the proximal and the middle phalanges, Kurzen et al. [3] found TAM below $180^{\circ}$ in $37 \%$ and an overall complication rate of $52 \%$.

The current study exclusively evaluates complications after low-profile plate fixation of extra-articular fractures of the proximal phalanx of the fingers in the absence of significant soft tissue damage. Intra-articular fractures, fractures of the thumb, open fractures grade II and III were excluded from this study, since these conditions 
include additional reasons for complications and restricted motion. In open fractures, revision of soft tissue with repair of injuries to the tendons, nerves, and arteries is indicated. The trauma triggered by injury plus iatrogenic dissection of the soft tissues may induce scar formation and additional adhesions that could be wrongly attributed to the plate fixation. Intra-articular fractures frequently require arthrotomy to control accuracy of articular reduction, leading to additional adhesion of the capsule. In the majority of cases, condylar fractures (distal onethird of the proximal phalanx) are not suitable for straightforward plate fixation. Fractures of the thumb were excluded from our study, since those fractures show different biomechanics and may require specific treatment strategies.

The exclusion criteria of the current study may permit a comparison of surgical results with outcome after functional conservative treatment. Open fractures grade I included in the current study are not a contraindication for functional conservative fracture treatment, provided that the skin lesions have been revised properly. In a multicenter study including 66 patients (75 fractures) treated with two different types of functional conservative casts, Franz et al. [9] reported good functional results and a high satisfaction rate among patients. The major concern with functional conservative fracture treatment is malunion of the proximal phalanx in palmar apex angulation. Fractures allowed to heal in palmar apex angulation have effectively lengthened the extensor apparatus, which results in PIP joint extension lag and MCP joint hyperextension moment caused by increased pull of the sagittal bands.

Compared to the results reported in the aforementioned study, functional outcome after ORPF of proximal phalanx fractures did not show any distinct advantage, even though improvement has been noted with the current low-profile titanium implants. If open reduction is indispensable, screw fixation without plating should be an option to achieve stable fracture fixation. If appropriate with the specific fracture configuration, the mid-axial surgical approach to the proximal phalanx could be an alternative to minimize extensor tendon interference [13-15]. If surgical intervention is advocated, patients need to be informed that the procedure may have its drawbacks such as finger stiffness and prolonged tissue swelling. Any surgical approach may act as a second insult to the injured tissue, causing further adherence of tendinous structures to the implants and bone, and probably requiring implant removal and tenolysis in the further cause [16].

Our study has several limitations. It is retrospective, and it is likely that there was surgeon selection bias toward plate fixation or conservative treatment. The retrospective design of the study led to varying follow-up intervals and resulted in incomplete data set (e.g., lack of DIP joint excursions in several patients). Statistical analysis is limited by the small cohort and by the lack of a control group. Nevertheless, it supports the findings of previous investigators with a rather high incidence of complications after ORPF of the proximal phalanges. We were unable to identify specific factors that account for the limited range of motion after ORPF. Alternative surgical options, such as screw fixation or pinning were not addressed in the study.

Conflict of interest All named authors hereby declare that they have no conflicts of interest to disclose. This research received no specific grant from any funding agency in the public, commercial, or not-for-profit sectors. The study has been approved by local institutional review board.

\section{References}

1. van Onselen EB, Karim RB, Hage JJ, Ritt MJ (2003) Prevalence and distribution of hand fractures. J Hand Surg Br 28(5):491-495

2. Chung KC, Spilson SV (2001) The frequency and epidemiology of hand and forearm fractures in the United States. J Hand Surg Am 26(5):908-915

3. Kurzen P, Fusetti C, Bonaccio M, Nagy L (2006) Complications after plate fixation of phalangeal fractures. $\mathrm{J}$ Trauma 60(4):841-843

4. Page SM, Stern PJ (1998) Complications and range of motion following plate fixation of metacarpal and phalangeal fractures. J Hand Surg Am 23(5):827-832

5. Belsky MR, Eaton RG, Lane LB (1984) Closed reduction and internal fixation of proximal phalangeal fractures. J Hand Surg Am 9(5):725-729

6. Harden RN, Bruehl S, Stanton-Hicks M, Wilson PR (2007) Proposed new diagnostic criteria for complex regional pain syndrome. Pain Med 8(4):326-331

7. Ebinger T, Erhard N, Kinzl L, Mentzel M (1999) Dynamic treatment of displaced proximal phalangeal fractures. J Hand Surg Am 24(6):1254-1262

8. Figl M, Weninger P, Hofbauer M, Pezzei C, Schauer J, Leixnering M (2011) Results of dynamic treatment of fractures of the proximal phalanx of the hand. J Trauma 70(4):852-856

9. Franz T, von Wartburg U, Schibli-Beer S et al (2012) Extraarticular fractures of the proximal phalanges of the fingers: a comparison of 2 methods of functional, conservative treatment. J Hand Surg Am 37(5):889-898

10. Pun WK, Chow SP, So YC et al (1991) Unstable phalangeal fractures: treatment by A.O. screw and plate fixation. J Hand Surg Am 16(1):113-117

11. Nalbantoglu U, Gereli A, Cilli F, Ucar BY, Turkmen M (2009) Open reduction and low-profile plate and/or screw fixation in the treatment of phalangeal fractures. Acta Orthop Traumatol Turc 43(4):317-323

12. Stern PJ, Wieser MJ, Reilly DG (1987) Complications of plate fixation in the hand skeleton. Clin Orthop Relat Res 214:59-65

13. Buchler U, Fischer T (1987) Use of a minicondylar plate for metacarpal and phalangeal periarticular injuries. Clin Orthop Relat Res 214:53-58

14. Lins RE, Myers BS, Spinner RJ, Levin LS (1996) A comparative mechanical analysis of plate fixation in a proximal phalangeal fracture model. J Hand Surg Am 21(6):1059-1064 
15. Ouellette EA, Dennis JJ, Latta LL, Milne EL, Makowski AL (2004) The role of soft tissues in plate fixation of proximal phalanx fractures. Clin Orthop Relat Res 418:213-218
16. Freeland AE, Hardy MA, Singletary S (2003) Rehabilitation for proximal phalangeal fractures. J Hand Therap 16(2): $129-142$ 